\title{
Histomorphology of Thymus Gland in Guinea Fowl (Numida meleagris)
}

\author{
S. Tamilselvan*, K. Balasundaram and S. Jayachitra \\ Department of Veterinary Anatomy, Veterinary College and Research Institute, Namakkal, \\ TANUVAS, Tamilnadu- 637002, India \\ *Corresponding author
}

\begin{tabular}{|c|c|}
\hline & A B S T R A C T \\
\hline $\begin{array}{l}\text { Ke y w o r d s } \\
\text { Histomorphology, } \\
\text { Thymus gland, } \\
\text { Guinea fowl } \\
\text { Numida } \\
\text { Meleagris. }\end{array}$ & \multirow{3}{*}{$\begin{array}{l}\text { The thymus was collected from day old to nine months of age at monthly interval. } \\
\text { Histomorphologically, the thymus gland in guinea fowl consists of cortex and } \\
\text { medulla. Cortex was composed of small and medium sized lymphocytes, myoid cells } \\
\text { and few Hassall's corpuscles located in the meshwork of reticular cells. The medulla } \\
\text { consisted of less densely packed medium and large sized lymphocytes with relatively } \\
\text { more reticular cells and Hassall's corpuscles. The reticuloepithelial cells were large } \\
\text { cells with long cytoplasmic process located in both the region. Myoid cells were } \\
\text { frequently found in the medulla and in the corticomedullary region, occasionally } \\
\text { found in the cortex. Hassall's corpuscles were observed commonly in the medulla and } \\
\text { less frequently in the cortical and corticomedullary junction. Plasma cells, mast cells, } \\
\text { erythrocytes and macrophages were found both in the cortex and medulla. }\end{array}$} \\
\hline Article Info & \\
\hline $\begin{array}{l}\text { Accepted: } \\
\text { 12 April } 2017 \\
\text { Available Online: } \\
10 \text { May } 2017\end{array}$ & \\
\hline
\end{tabular}

\section{Introduction}

The thymus gland is a lymphoid tissue derived from III and IV pharyngeal pouches. It is the source of stem cells that migrate to other lymphoid organs and participate in immune reactions (Kent, 1978). The thymus gland is regarded immunologically as a primary or central lymphoid organ and its presence is essential for the development of peripheral lymphoid tissues and their associated adaptive immune functions (Clawson, 1967). The thymus produces precursors of cells (T-cells) involved in specific cell mediated immune responses and co-operate with B - cells in the production of antibodies. It has a significant role in immune system of birds. Hence, the present study was undertaken due to its importance in immunological competence and to provide microscopic details of thymus in guinea fowl.

\section{Materials and Methods}

The thymus gland was collected from apparently healthy guinea fowls (pearl variety) from Instructional Poultry Farm, Veterinary College and Research Institute, Namakkal-02 and Poultry Research Station, Madhavaram Milk Colony, Chennai-51. The thymus gland was collected from different age groups of guinea fowl ranging from day old to nine months, a monthly interval. Totally nine groups (fifty four birds) and each group consisted of six birds ( 3 males and 3 females) were utilized for this study. The 
tissues were fixed in 10 per cent neutral buffered formalin and then processed through ascending grades of alcohol, cleared in xylene and embedded in paraffin wax at $58-60^{\circ} \mathrm{C}$. Sections of 3-5 $\mu \mathrm{m}$ thickness were made and stained with Haematoxylin-Eosin method, Van Gieson, Masson trichrome techniques and PTAH for collagen fibres, Verhoeff's method for elastic fibres, Gomori's method for reticular fibres (Bancroft and Stevens, 1996), Methyl green-pyronin method for plasma cells (Pappenheim, 1899) and Unna's method (Luna, 1968) for mast cells.

\section{Results and Discussion}

The thymus gland of guinea fowl was enclosed by a connective tissue capsule. The connective tissue originated from capsule and extended all the way into lobes dividing them into indistinct lobules. This concurs with the results of Lochi et al., (2014) and Singh et al., (2010) in Chicken and Sultana et al., (2011) in ducklings. In the thymus of guinea fowl, the capsule and trabeculae were made up of mainly collagen (Fig. 1, 2 and 3) and reticular fibres (Fig. 4) with few elastic fibres as observed by Firth (1977) in chicken. As stated by Shriprakash (2004), each lobe was indistinctly lobulated and those lobules were marginally positioned with advancing age. The lobes were divided into outer darkly stained cortex and inner palely stained medulla (Fig. 5). This is not in accordance with Sultana et al., (2011) and Lochi et al., (2014) observed that each lobule organized into a peripheral cortex and a central medulla in ducklings and in chicken respectively.

Cortex in each lobe was composed of more small and medium lymphocytes and myoid cells were located in the meshwork of reticular cells. These lymphocytes were closely packed hence it appeared as darkly stained zone in each lobe. This finding is in accordance with Gilmore et al., (1974) in domestic fowl, Leena et al., (2008) in Giriraja birds and Singh et al., (2010) in chicken. The medulla consisted of less densely packed medium and large lymphocytes with relatively more reticular cells, myoid cells and Hassall's corpuscles. It appeared as lightly stained zone in the centre of the lobe. This is similar with that of Sultana et al., (2011) in ducklings.

The reticuloepithelial cells were large cells with long cytoplasmic process located both in the cortex and medulla. The cytoplasm of the reticular cells was packed with small vacuoles. This observation concurs with Singh et al., (2010) in chicken and Leena et al., (2012) in Giriraja birds. The thymocytes were of three types based on their size viz, small, medium and large lymphocytes. The small and medium sized thymocytes were located in the cortex and medium and large lymphocytes were seen in medulla. These findings are in accordance with Hashimoto and Sugimura (1976) in white pekin ducks.

Myoid cells were frequently found in the medulla, corticomedullary region and occasionally found in the cortex as reported by Hashimoto and Sugimura (1976) in White pekin ducks, Raviola and Raviola (1967) in pigeons and Gilmore et al., (1974) in domestic fowl. In the present study two types of myoid cells were observed. Type I cells were elongated in shape with oval nucleus and the cytoplasm was homogenous, eosinophilic and hyaline in nature. The nucleus was placed in the centre with few chromatin granules. The majority of the nucleus contained single nucleoli. Binucleated cells were occasionally seen as recorded by Gilmore et al., (1974) in domestic fowl. Type II cells were spherical in shape with rounded eccentrically placed nucleus and homogenous eosinophilic cytoplasm. This observation is similar to that the findings of Sugimura et al., (1975) in duck. 
Fig.1 Showing Collagen Fibres (CF) in the interlobular septa Van Gieson x100

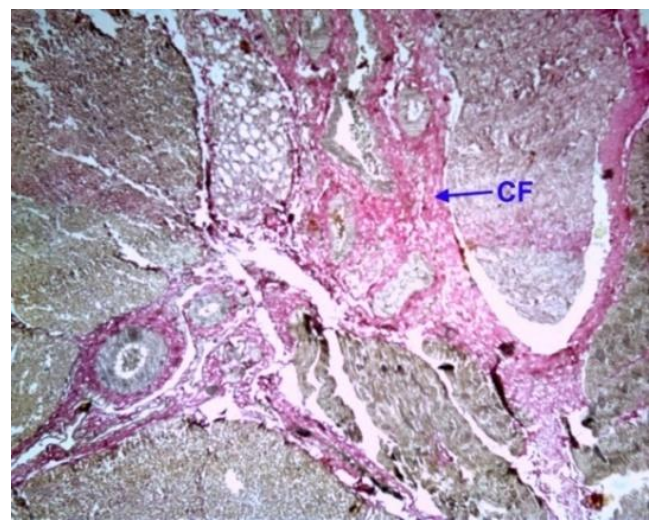

Fig.2 Showing Collagen Fibres (CF) in the interlobular septa and capsule Masson Trichrome x100

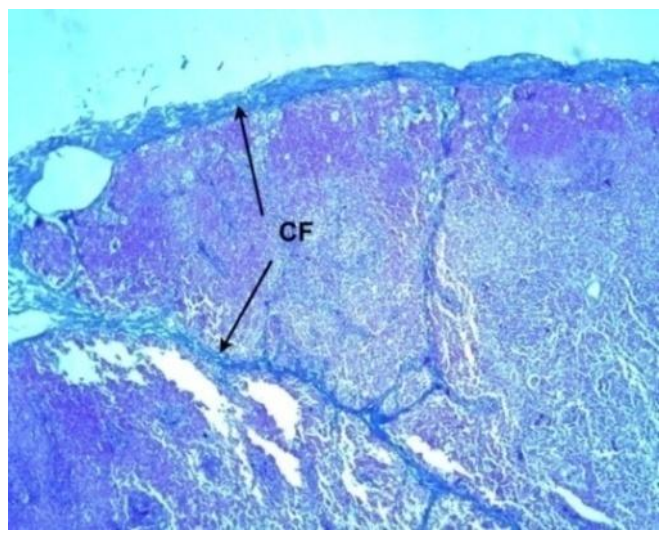

Fig.3 Showing collagen fibres $(\mathrm{CF})$ in the interlobular septa and capsule PTAH x 100

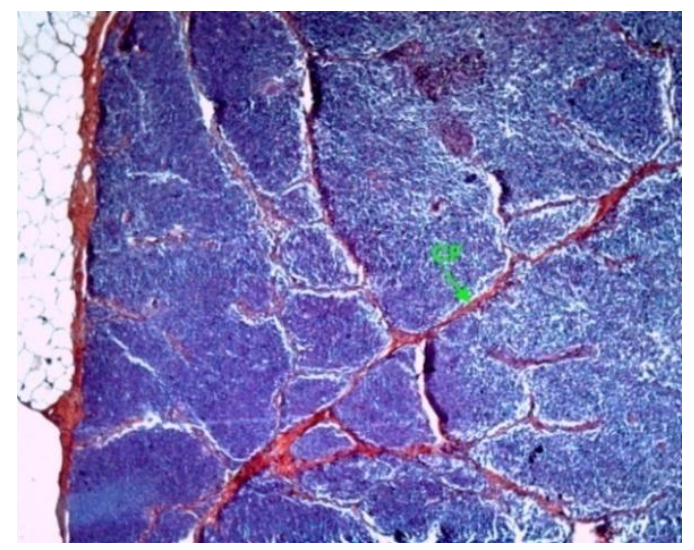


Fig.4 Showing Reticular Fibres (RF) in the interlobular septa Gomori's method x400

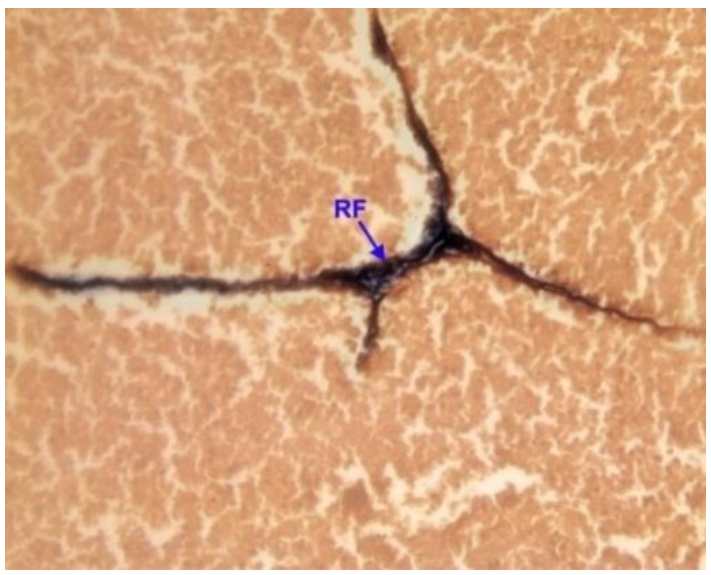

Fig.5 Showing thymic lobe with Capsule (C), Cortex (Cx), Medulla (M), Indistinct InterLobular Connective tissue (ILC), H\&E x400

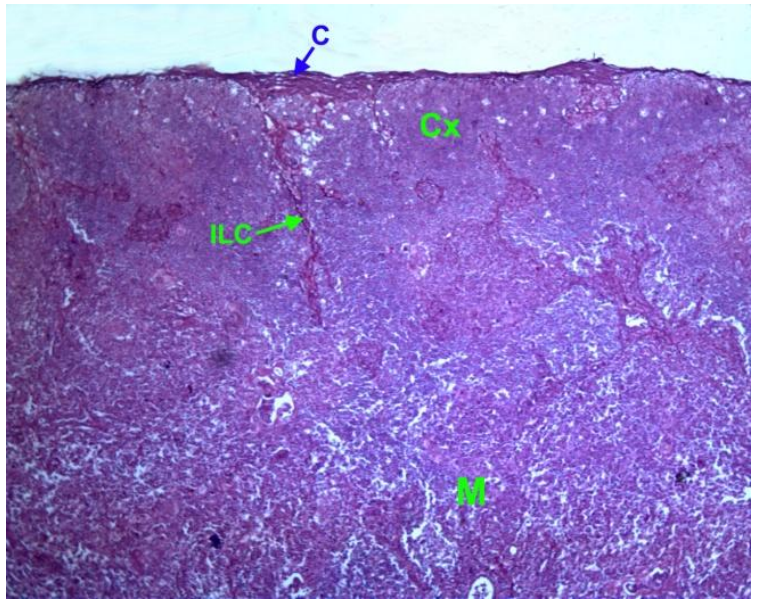

Fig.6 Showing Hassall's Corpuscles (HC) in the cortical region $\mathrm{H} \& \mathrm{E}$ x 400

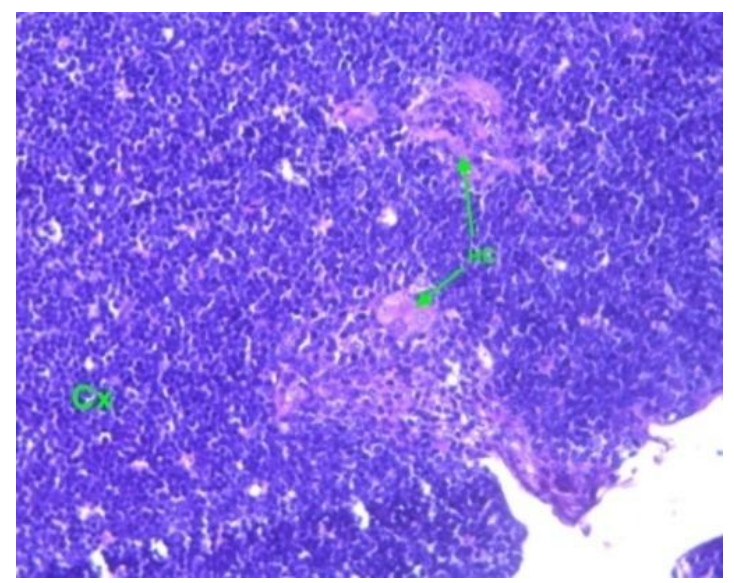


Fig.7 Showing Hassall's corpuscles (Arrow) in the medulla $\mathrm{H} \& \mathrm{E} \times 1000$

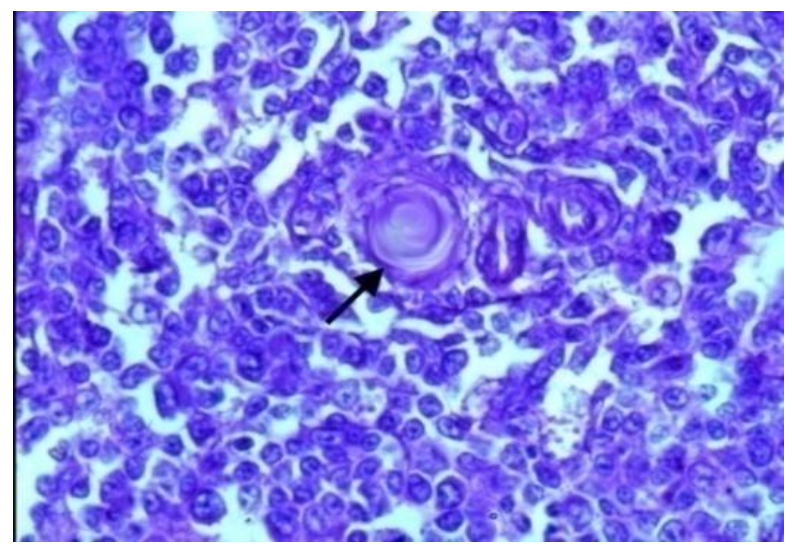

Fig.8 Showing cyst filled with cells (Arrows) in the medullary region H\&E x100

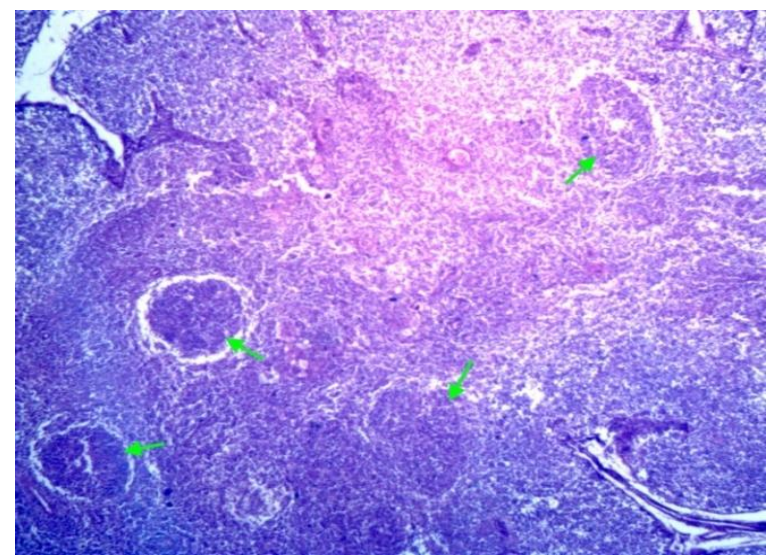

Fig.9 Showing depletion of lymphocytes in medullary region. H\&E x100

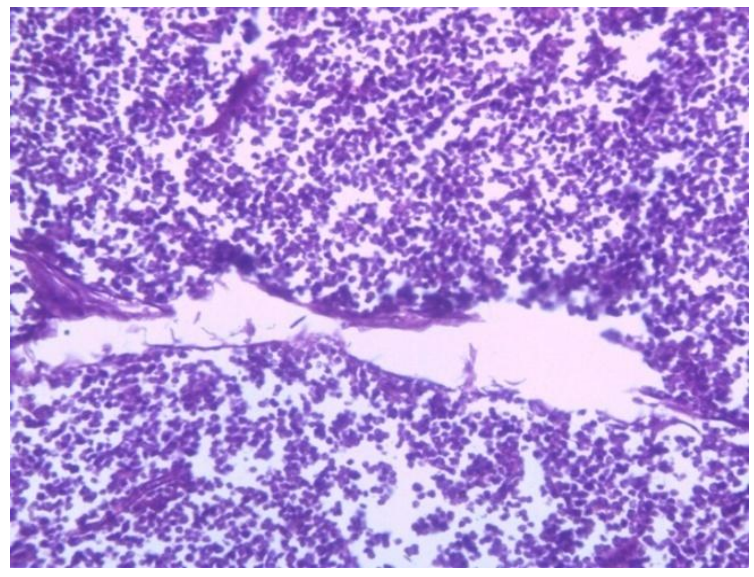

Hassall's corpuscles were observed frequently in medulla and less frequently in the corticomedullary and cortical region (Fig. 6) as observed by Kendall (1980) in chicken, Hashimoto and Sugimura (1976) in White Pekin ducks and Vijayaragavan (1988) in 
White Leghorns. Hassall's corpuscles were spherical in shape lined by flattened reticuloepithelial cells, arranged in concentric fashion enclosing a hyaline mass with a group of cells (Fig. 7) as recorded by Muthukumaran (2008) in turkeys.

Plasma cells were found beneath the capsule in the perivascular space, cortex and medulla. This observation is in accordance with Kendall (1980) in weaver bird and Singh et al., (2010) in chicken. The Mast cells were observed in the parenchyma as well as in the stroma of the thymus in both the sexes of guinea fowls. Their number increased as the age advances in both the sexes as mentioned by Vijayaragavan (1988) in White Leghorn chicken. Mast cells density was higher in close proximity to the arterial vessels and medullary region of thymus than in the cortical region as stated by Karaca et al., (2006) in chicken and Leena et al., (2008) in Giriraja birds.

Erythrocytes were found in the cortex and corticomedullary border of thymus gland as stated by Fonfria et al., (1983) in birds. Macrophages were more in the corticomedullary junction and also in cortex and medulla in all the age groups. This finding is agreeable with the finding of Leena et al., (2008) in Giriraja birds. Heterophils were observed both in medulla and cortex. But Lucas and Jamroz (1961) and Kendall (1980) reported that the heterophils were commonly present in the medulla of chicken. Cysts were variable in shape and size enclosing reticuloepithelial cells, lymphocytes and myoid cells and more number of epithelial cysts was found in the medulla (Fig. 8) of male thymus as observed by Casey and Morris (1975) in growing cockerels, Vijayaragavan (1988) in White Leghorn birds and Leena et al., (2008) in Giriraja birds. The involution of thymus gland, caused thickening of capsule, loss of interlobular septa, depletion of lymphocytes especially in cortex than in the medulla (Fig. 9) and enlargement of reticular cells as observed by Nicander $e t$ al., (1993), Kendall (1980) and Bhattacharya (1983) in chicken. The size and number of Hassall's corpuscles increased during involution as stated by Bhattacharya (1983) in thymus gland of birds.

In conclusion, the thymic lobes were divided into cortex and medulla. Cortex was composed of small and medium lymphocytes; myoid cells and few small Hassall's corpuscles were located in the meshwork of reticular cells. The medulla consisted of less densely packed medium and large lymphocytes with relatively more reticular cells and Hassall's corpuscles. Hassall's corpuscles were observed commonly in the medulla and less frequently in the cortical and corticomedullary region. Plasma cells, mast cells, erythrocytes and macrophages were found both in the cortex and medulla. Cysts of variable shape and size enclosing the reticuloepithelial cells, lymphocytes and myoid cells were also observed.

\section{Acknowledgements}

The authors are thankful for the support of Tamilnadu Veterinary and Animal Sciences University, Chennai, Tamilnadu-600051, India

\section{References}

Bancroft, J.D and Stevens, A. 1996. Theory and Practice of Histological Techniques. $\quad 4^{\text {th }}$ Edn., Churchill Livingstone, Edinburgh, London.

Bhattacharya, B.K. 1983. Some Histomorphological and Cytochemical changes in the during spontaneous age involution. Pavo., 21: 71-85.

Casey, M.J. and Morris. G.P. 1975. Ultrastructural and quantitative studies 
on thymic cysts in the developing cockerels. Proc. Cah. Fed. Biol., 18: 432.

Clawson, C.C., Cooper, M.D and Good, R.A. 1967. Lymphocyte fine structure in the bursa of Fabricius, the thymus and the germinal centers. Lab. Inves., 16: 407421.

Firth, G.A. 1977. The normal lymphatic system of the domestic fowl. Vety. Bull., 47: 167-179.

Fonfria, J., Barrutia, M.G., Garrido, E., Ardavin, C.F and Zapata, A. 1983. Erythropoiesis in the thymus of the spotless starling, Sturnus unicolor. Cell. Tiss. Res., 232: 445 -455.

Gilmore, C., Ruth, S.T and Bridges, B. 1974. Histochemical and ultrastructural studies on the Myoid cells of the thymus of the domestic fowl (Gallus domesticus). J. Anat., 118(3): 409- 416.

Hashimoto, Y. and Sugimura, M. 1976. Histological and quantitative studies on the postnatal growth of the thymus and the bursa of Fabricius of White Pekin ducks. Jap. J. Vet. Res., 24: 65 - 76.

Karaca, T., Yoruk, M and Uslu, S. 2006. Agerelated changes in the number of mast cells in the avian lymphoid organs. Anat. Histol. Embryol., 35: 375 - 379.

Kendall, M.D. 1980. Avian thymus glands. A Review. Dev. Comp. Immunol., 4: 191 210.

Kent, G.C. 1978. Comparative Anatomy of Vertebrates. $4^{\text {th }}$ Edn, The C.V. Mosby Company, Saint Louis.

Leena, C., Prasad R.V and Jamuna, K.V. 2012. Ultrastructural studies of involuting bursa and thymus of giriraja birds (Gallus domesticus). Int. J. Poult. Sci., 11(6): 397- 399.

Leena, C., Prasad, R.V., Kakade, K. and Jamuna, K.V. 2008. Histology and Age related involuntary changes of the thymus of Giriraja birds (Gallus domesticus). J. Vet. Anim. Sci., 39: 40-
43.

Lochi, G.M., Haseeb, A., Shah, M.G., Gandahi, J.A., Khan, M.S., Faisal, M., Kiani, F.A., Mangi, R.A. and Oad, S.K. 2014. Histo-morphological study on thymus of aseel chicken. J. Agric. Food. Tech., 4(2): 1-5.

Lucas, A.M. and Jamroz, C. 1961. Atlas of Avian Haematology. Agric. Monogr. washington, U.S.A. pp.25,

Luna, L.G. 1968. Manual of histological staining methods of the armed forces institute of pathology, $3^{\text {rd }}$ Edn., McGraw Hill Book Co., New York. pp: 95.

Muthukumaran, C. 2008. Gross and microanatomical studies on the thymus gland of turkeys. Thesis submitted for the award of M.V.Sc to the Tamilnadu veterinary and animal sciences university, Chennai.

Nicander, L., Brown, E.M., Dellmann, H.D and Landverk, T. 1993. In Dellmann. H.D. (ed). lymphatic Organs. The Text Book of Veterinary Histology. Lea and Febiger. Philadelphia, pp: $120-135$.

Pappenheim, A. 1899. Vergleichende Untersuchungen uber die elementure Zusammen setzung des rothen knockenmarkes einiger saugenthiere. Virchows Archivtur Pathologische Anatomie Physiologie, 157: 19. Cited in Bancroft, J.D. and A. Stevens, 1996. Theory and Practice of Histological Techniques. $\quad 4^{\text {th }}$ Edn. Churchill Livingstone, Edinburgh, London.

Raviola, E and Raviola, G. 1967. Striated muscle cells in the thymus of reptiles and birds. An electron microscopic study. Am. J. Anat., 121: 623 - 646.

Shriprakash, S. 2004. Structural and functional development of lymphoid organs in guinea fowl. Thesis submitted for the award of M.V.Sc., to the GBPUAT, Pantnagar, Uttarakhand.

Singh, G.K., Chauhan, R.S and Mishra, U.S. 2010. Histomorphological development 
of lymphoid organs in chicken: thymus and bursa of Fabricius. J.Immunol. Immunopathol. 12(1): 20-28.

Sugimura, M., Hashimoto, Y and Yamada, J. 1975. Morphology of bursa of Fabricius in bursectomized and thymectomized ducks. Jap. J. Vet. Res., 23: 17 - 24.

Sultana. N., Khan, M.Z.I., Wares, M.A and Masum, M.A. 2011. Histomorphological study of the major lymphoid tissues in indigenous ducklings of Bangladesh. Bang. J. Vet. Med., 9(1): 53-58.

Vijayaragavan, C. 1988. Microanatomical studies of thymus in white leghorn birds. Thesis submitted for the award of Ph.D to the Andra Pradesh agricultural university, Hyderabad.

\section{How to cite this article:}

Tamilselvan, S., K. Balasundaram and Jayachitra, S. 2017. Histomorphology of Thymus Gland in Guinea Fowl (Numida meleagris). Int.J.Curr.Microbiol.App.Sci. 6(5): 1076-1083. doi: https://doi.org/10.20546/ijcmas.2017.605.117 